\title{
The anxiety and loneliness levels of geriatric population in-home quarantine during COVID-19 pandemic in Turkey
}

\author{
Türkiye'de COVID-19 salgını sırasında ev karantinasındaki geriatrik \\ popülasyonun kaygı ve yalnızlık düzeyleri
}

\author{
Oğuzhan Kılınçel11, Gürkan Muratdağı2 ${ }^{2}$, Abdülkadir Aydın³, Ahmet Öksüz4, Yıldız Büyükdereli \\ Atadağ 5 , Erkut Etçioğlu², Feride Özen² \\ ${ }_{1}$ M.D, Sakarya Yenikent State Hospital, Department Of Psychiatry, Sakarya, Turkey https://orcid.org/0000-0003-2988-4631 \\ 2M.D, Sakarya University Faculty of Medicine, Department of Family Medicine, Sakarya, Turkey https://orcid.org/0000-0002-9629-3973 \\ https://orcid.org/0000-0002-8117-7929-https://orcid.org/0000-0003-0009-4433 \\ 3 M.D, Sakarya University Training and Research Hospital, Department of Family Medicine, Sakarya, Turkey https://orcid.org/0000-0003- \\ 0663-586X \\ ${ }^{4}$ M.D, Mimarsinan Family Health Center, Sivas, Turkey https://orcid.org/0000-0002-1556-8171 \\ 5 M.D, Bağlarbaşı Family Health Center, Gaziantep/Turkey https://orcid.org/0000-0002-8516-6477
}

SUMMARY

Objective: Mortality rates of COVID-19 are higher among the elderly. Curfews have been imposed on individuals aged 65 and older to reduce contact with other people. We aimed to determine anxiety and loneliness levels and associated factors of individuals aged 65 and over in-home quarantine. Method: We determined sociodemographic, clinical features, information status on COVID-19 pandemic, geriatric anxiety scale and loneliness scale for the elderly values of 290 individuals (6590 years old) in Turkey. Results: The mean age was $71.2 \pm 5.9$ years, and $54.8 \%$ were male(n: 159). $87.6 \%$ followed COVID-19 process, and $88.3 \%$ received the information from the television. $14.1 \%$ reported significant worries about the individuals in their family, $14.1 \%$ about their social life, and $19.7 \%$ about their economic situation. A statistically significant relationship was observed between the geriatric anxiety and the loneliness scale(r: 0.498, p: 0.001). Anxiety scores were increased 1.29 fold by loneliness scores, 3.56 fold by having a chronic disease and 3.26 fold by the history of a psychiatric disorder. Discussion: We suggest that quarantine increases anxiety and loneliness levels in geriatric population with a positive correlation between anxiety and loneliness levels. Having a chronic disease and History of a psychiatric disorder was also associated with anxiety levels. The majority of concerns is about their family members, future social and economic lives. It has been observed that television has become an essential source of information in the pandemic for the geriatric population. Authorities should meet the psychosocioeconomic needs of elderly individuals, and correct information should be provided.

Key Words: Anxiety, coronavirus, geriatrics, loneliness, quarantine

(Turkish J Clinical Psychiatry 2020;23 (Supp 1):7-14)

DOI: $10.5505 / \mathrm{kpd} .2020 .04382$

\section{ÖZET}

Amaç: COVID-19'da yaşlılardaki mortalite, bağışıklık sisteminin zayıf olması ve sıklıkla kronik hastalıkların eşlik etmesi nedeniyle daha yüksektir. Diğer insanlarla teması azaltmak için 65 yaş ve üzerindeki kişilere sokağa çıkma yasağı getirilmiştir. Çalışmamızda evde karantinadaki 65 yaş ve üzeri bireylerin kaygı ve yalnızlık düzeylerini belirlemeyi amaçladık. Yöntem: Tanımlayıcı araştırmamız i 8 aile sağlığı merkezine kayıtlı 290 kişiden (65-90 yaş) oluşmaktadır. Katılımcıların sosyodemografik ve klinik özellikleri, COVID-19 salgını ile ilgili bilgi durumları ve yaşlılar için geriatrik anksiyete ile yalnızlık ölçeği verileri değerlendirildi. Bulgular: Katılımcıların yaş ortalaması $71.2 \pm 5.9$ yıldı ve \% 54.8'i erkekti (n: 159). Covid-19 sürecini \%87,6'sı takip ettiğini belirtmiş olup bunların \%88.3'ü televizyondan takip ettiğini belirtti. \%14.1'i aileleri, \%19.7'si erkonomik durumları, \%14.1'i sosyal yaşantılarıyla ilgili kaygılandıklarını belirtti. Geriatrik anksiyete ölçeği ile yalnızlık ölçeği arasında istatistiksel olarak anlamlı bir ilişki gözlendi ( $r$ : 0.498, p: 0.001). Anksiyete puanlarının yalnızlık puanları 1.29 kat, kronik hastalığı olanlarda 3.56 kat ve psikiyatrik bozukluk öyküsü olanlar 3.26 kat artış ile ilişkili olduğu gözlendi. Sonuç: Çalışmamızda ev karantinasının geriatrik popülasyonda anksiyete ve yalnızlık düzeylerini arttırdığı, bu popülasyonun endişelerinin çoğunun aile üyeleri, gelecekteki sosyal ve ekonomik yaşamlarıla ilgili olduğu tespit edildi. Kronik bir hastalığa veya psikiyatrik bozukluk öyküsü de anksiyete düzeylerinin yüksek olması ile ilişkilendirildi. Televizyonun geriatrik popülasyon için pandemideki en önemli bilgi kaynağı oldu gözlendi. Yetkililer ve sosyal organizasyonlar yaşlı bireylerin psikososyoekonomik ihtiyaçlarını karşılamalı ve doğru bilgi sağlamalıdır.

Anahtar Sözcükler: Anksiyete, koronavirüs, geriatri, yalnızlık, karantina 


\section{INTRODUCTION}

COVID-19, the New Coronavirus Disease, spread rapidly around the world after its emergence in December 2019 and was declared as a pandemic by the World Health Organization on March 11, 2020 (1). In Turkey, the first case was also announced by the Ministry of Health on March 11, 2020 (2). Although COVID-19 affects individuals of all ages, older individuals are more vulnerable to the infection because their immune systems are weaker, and they are more likely to have chronic diseases (3). Mortality rates are also higher in the elderly population (4). Data showed a mortality risk of $3.6 \%$ for individuals aged 60 years and $8.0 \%$ and $14.8 \%$ for individuals aged 70 and 80 years, respectively (5). Therefore, social isolation providing less contact with people is recommended to reduce infectionrelated mortality rates (5). In our country, as of the evening of March 21, 2020, curfew was imposed on individuals 65 years old and over without an expiry date (2). Although these precautions protect the physical health of individuals, it can lead to numerous mental problems (6). The prevention of daily activities such as shopping, worshipping, and socializing, which are the ways older individuals mostly communicate with people, makes them feel lonely (7). Social isolation and loneliness are interrelated, but different concepts. Social isolation implemented due to the pandemic includes ceasing physical contact with other family members and friends, communicating with people who distribute food and other needs by keeping at least two meters apart and avoiding social activities involving physical contact (8). Loneliness is defined as the feeling of anxiety and dissatisfaction caused by the decrease in the quality and quantity of the individual's participation in social activities and the lack of communication with other individuals (9). Cardiovascular diseases, neurocognitive dysfunction, and mental disorders such as depression and anxiety are increasingly observed among elderly individuals who must stay at home for a long time due to the quarantine $(10,11)$.

Individuals' experiences of illness, death, mourning and loss, along with the feeling of insecurity increase with age (12). Thoughts of worthlessness and being a burden on others also emerge (7). Some individuals receive care support from social services and various organizations due to lack of adequate support from family and friends (13). Therefore, older individuals are the most vulnerable group to loneliness, even under normal conditions. Considering these facts, some countries developed various health policies to reduce the sense of loneliness caused by ageing before the pandemic. In the UK, a network of national, regional, and local organizations have been established with campaigns slogans 'End Loneliness' (14). Positive ageing principles have been developed to promote community participation and prevent social isolation in New Zealand (15).

In many countries, quality of life decreased in older adults, especially individuals with chronic diseases who live alone, due to the suspension of most health and social support services after the start of COVID-19 outbreak. Economic difficulties and unemployment in the SARS epidemic mostly affected the young population, while medical, social and community support deficiencies were found to affect the elderly. These traumatic experiences also make individuals more susceptible to fear and anxiety during this period (16).

Reports of high mortality rates in infected elderly patients increase the fear of infection and death in this population. Also, the fact that most people obtain information about COVID-19 prevention and mental health protection from internet, and media such as radio and television, some of these sources provide false and inadequate information, and the inability to follow correct sources increase this fear (17). Caregivers should wear personal protective equipment to reduce contamination while serving older adults at home. This causes intolerance and misunderstanding, especially in individuals with cognitive impairment. Furthermore, it has been reported that some individuals cancel home care services to minimize face-to-face contact due to the fear of virus transmission (18). Consequently, they feel more alone.

It is of immense importance to identify risky groups and risk factors to organize treatment strategies and health policies in disease processes affecting the entire society. Knowing the basis of psychopathologies, immensely those unique to risk 
groups help to the management of clinicians and also guides for taking precautions to decrease the severity of the developing psychopathology. There are studies showing that pandemic periods increase anxiety and loneliness (19). However, it is noteworthy that the studies examining the effects of these two emotions on each other are limited. In our study, we aimed to evaluate the effect of home quarantine, one of the precautions taken for the pandemic, on anxiety and loneliness levels of individuals aged 65 and over and also to determine the associated factors.

\section{METHODS}

\section{Study design and participants}

Geriatric population (individuals aged between 6590 years) registered at eight Family Health Centers in Turkey, constituted the universe of this descriptive study. Exclusion criteria were alcohol-substance abuse and neurological diseases (History of dementia, cerebrovascular disease) that might affect cognitive functions. The sociodemographic survey was used to obtain sociodemographic features including age, gender, place of residence, cohabitants and education level. The presence of chronic diseases and psychiatric disorders, the smoking status as well as the information status of the participants about COVID-19 pandemic were also recorded. Anxiety and loneliness levels were evaluated by using the Geriatric Anxiety Scale and the Loneliness Scale for the Elderly. The family physicians filled out surveys and scales during video calls with illiterate participants and online by other participants themselves. This study was approved by the Ethical Committee of Sakarya University with approval no:71522473/050.01.04/237 and date 20.05.2020. All participants signed informed consent, and their anonymity is preserved. The stages of sample selection are shown in Figure 1.

Geriatric Anxiety Scale (GAS): The scale was developed by Pachana et al. in 2007 (20). It comprises 20 items and two dimensions. The total score ranges between 0 and 20 . The primary psychometric feature of this scale is its ability to distinguish between groups with and without anxiety. The Cronbach-alpha value of the scale is 0.93 , and the same value is 0.91 for the Turkish validity study $(20,21)$.

Loneliness Scale for the Elderly (LSE): LSE, comprising 11 triple Likert-type items to measure social and emotional loneliness, was developed by De Jong Gierveld in 1999 (22). It contains positive and

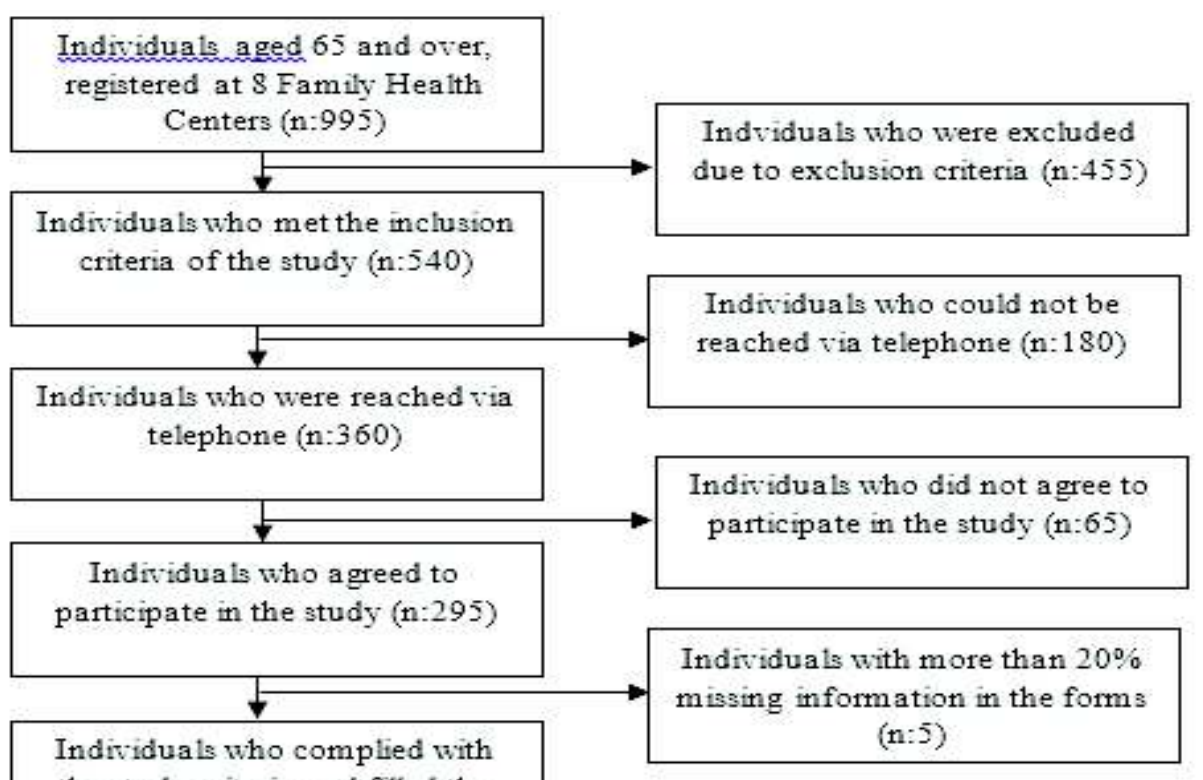

Figure 1. The sampling process of the study. 
Table 1. Sociodemographic features of the participants

\begin{tabular}{lll}
\hline \multicolumn{2}{l}{ Sociodemographic Feature } & \\
\hline Age & & $71.2-5.9 *$ \\
\hline \multirow{2}{*}{ Gender } & & Percentages and (n) of the participants \\
\hline Place of residence & City center & (n:290) \\
\cline { 2 - 3 } & Metropolitan center & $54.8 \%$ male (n:159) \\
\cline { 2 - 3 } & District center & $56.9 \%(\mathrm{n}: 165)$ \\
\cline { 2 - 3 } & Town/village & $32.1 \%(\mathrm{n}: 93)$ \\
\hline Cohabitants & Spouse & $5.9 \%(\mathrm{n}: 17)$ \\
\cline { 2 - 3 } & Spouse and children & $5.2 \%(\mathrm{n}: 15)$ \\
\cline { 2 - 3 } & Children & $20.7 \%(\mathrm{n}: 147)$ \\
\cline { 2 - 3 } & Alone & $16.6 \%(\mathrm{n}: 59)$ \\
\cline { 2 - 3 } & Not disclosed & $9.7 \%(\mathrm{n}: 28)$ \\
\hline Education level & Primary school & $2.7 \%(\mathrm{n}: 8)$ \\
\cline { 2 - 3 } & Illiterate & $36.6 \%(\mathrm{n}: 106)$ \\
\cline { 2 - 3 } & College and above & $22.1 \%(\mathrm{n}: 64)$ \\
\cline { 2 - 3 } & Literate without a diploma & $13.5 \%(\mathrm{n}: 45)$ \\
\cline { 2 - 3 } & Highschool & $6.9 \%(\mathrm{n}: 20)$ \\
\cline { 2 - 3 } & Middle school & $5.9 \%(\mathrm{n}: 17)$ \\
\hline
\end{tabular}

*Age is presented as (mean-SD).
negative statements, and high scores represent the total level of loneliness. The total scores range from 0 to 22 . In the Turkish validity study, the Cronbach alpha value was 0.85 (23).

\section{Statistical Analysis}

The research data were statistically analyzed with SPSS (Statistical Package for Social Sciences) for Windows 21.0 (SPSS Inc0. Chicago, IL). Descriptive statistics were presented as mean \pm standard deviation (SD) and percentages. Normality was examined using visual (histogram and probability graphs) and analytical methods (Kolmogorov-Smirnov / Shapiro-Wilk tests). The Pearson Correlation test evaluated the relationship between the variables. Pearson $r$ coefficients of $0.10-0.30,0.30-0.50$, and 0.50-1.00 were considered weak, medium, and strong effect size, respectively. GAS score 10 accepted as cut-off point and logistic regression analysis were applied with the retrospective elimination between groups. The value of $\mathrm{p}$ $<0.05$ was accepted as statistically significant.

\section{RESULTS}

\section{Sociodemographic features}

We examined the data of 290 individuals with a mean age of $71.2 \pm 5.9$ years, among which $54.8 \%$ were male (n: 159). The sociodemographic data of the participants are shown in Table 1.

\section{Chronic medical diseases, psychiatric disorders and smoking status}

It was observed that $69.0 \%$ of the participants had chronic diseases, while $9.7 \%$ had previous psychiatric disorders, and $8.6 \%$ is currently smoking.

Table 2. The presence of chronic medical diseases, psychiatric disorders and smoking status

\begin{tabular}{lll}
\hline & & Percentages and (n) of the participants \\
\hline Having a chronic disease & $69.0 \%(\mathrm{n}: 200)$ \\
\hline History of a psychiatric disorder prior to the pandemic & $9.7 \%(\mathrm{n}: 28)$ \\
\hline \multirow{2}{*}{$\begin{array}{l}\text { Smoking } \\
\text { status }\end{array}$} & Never smoked & $61.4 \%$ (n:178) \\
\cline { 2 - 3 } & Quit & $30.0 \%(\mathrm{n}: 87)$ \\
\cline { 2 - 3 } & $\begin{array}{l}\text { I still smoke at the same frequency as before the } \\
\text { pandemic }\end{array}$ & $4.8 \%$ (n:14) \\
\cline { 2 - 3 } & I still smoke but less frequently than before the pandemic & $3.1 \%(\mathrm{n}: 9)$ \\
\cline { 2 - 3 } & $\begin{array}{l}\text { I still smoke but more frequently than before the } \\
\text { pandemic }\end{array}$ & $0.7 \%(\mathrm{n}: 2)$ \\
\hline
\end{tabular}


The anxiety and loneliness levels of geriatric population inhome quarantine during COVID-19 pandemic in Turkey

Table 3. Information status of the participants about COVID-19 pandemic

\begin{tabular}{|c|c|c|}
\hline & & $\begin{array}{l}\text { Percentages and }(n) \text { of } \\
\text { the participants }\end{array}$ \\
\hline \multirow{2}{*}{$\begin{array}{l}\text { Do you follow the data regarding the COVID-19 disease? (Number of } \\
\text { patients, number cured, deceased) }\end{array}$} & Yes & $87.6 \%(\mathrm{n}: 254)$ \\
\hline & No & $12.4 \%(\mathrm{n}: 36)$ \\
\hline \multirow{4}{*}{$\begin{array}{l}\text { Which of the following sources of information do you mostly use to } \\
\text { get informed about COVID-19 disease? }\end{array}$} & $\mathrm{TV}$ & $88.3 \%(\mathrm{n}: 256)$ \\
\hline & $\begin{array}{l}\text { People I am in contact } \\
\text { with }\end{array}$ & $8.3 \%(\mathrm{n}: 24)$ \\
\hline & Social Media & $3.1 \%(\mathrm{n}: 9)$ \\
\hline & Radio & $0.3 \%(\mathrm{n}: 1)$ \\
\hline \multirow{2}{*}{$\begin{array}{l}\text { Do you think that you need further information about COVID-19 } \\
\text { pandemic? }\end{array}$} & Yes & $36.2 \%(\mathrm{n}: 105)$ \\
\hline & No & $63.8 \%(\mathrm{n}: 185)$ \\
\hline
\end{tabular}

Table 2 shows the presence of chronic medical diseases, psychiatric disorders, and smoking status.

\section{Information status about COVID-19 pandemic}

It was observed that $87.6 \%$ of the participants followed the developments, and $88.3 \%$ received the information from the TV. Table 3 shows the Information status of participants about COVID19 pandemic.

\section{Anxiety and loneliness levels of the participants}

$14.1 \%$ of the participants reported that they were severely worried about the individuals in their family, $10.1 \%$ about their social life, and $19.7 \%$ about their economic status. Geriatric anxiety level median was 4 (Q1:1.0 - Q4:11.0), and loneliness level median was 6.5 (Q1: 4.0-Q4: 11.2). Table 4 shows the levels of anxiety associated with the COVID outbreak. A significant relationship was observed between the geriatric anxiety scale and the loneliness scale (r: 0.498, p: 0.001), as shown in Figure 2.
The association of anxiety levels with the variables

The association of anxiety levels with age, smoking status, LSE, having a chronic disease, History of a psychiatric disorder before the pandemic, the information status of the participants were determined. Anxiety scores were increased 1.29 fold by LSE, 3.56 fold by having a chronic disease and 3.26 fold by the History of a psychiatric disorder, in the anxiety group compared to non-anxiety group as presented in Table 5.

\section{DISCUSSION}

We examined the effects of home quarantine on anxiety and loneliness levels, as well as the affecting factors in geriatric population in Turkey and determined that anxiety levels are in this population with approximately $14 \%-20 \%$ of them are significantly worried about other individuals in their family. We also determined that loneliness are positively correlated with anxiety levels. Also, $87.6 \%$ of the participants followed the developments related to COVID-19 and $88.3 \%$ obtained the information

Table 4. Familial, social, economic anxiety levels related to COVID pandemic

\begin{tabular}{lll}
\hline \multirow{2}{*}{$\begin{array}{l}\text { What is your level of worry about other } \\
\text { individuals in your family getting COVID- }\end{array}$} & Mildly worried & Percentages and (n) of the participants \\
\cline { 2 - 3 } 19 disease? & Somewhat worried & $19.7 \%(\mathrm{n}: 95)$ \\
\cline { 2 - 3 } & Not worried at all & $18.6 \%(\mathrm{n}: 54)$ \\
\cline { 2 - 3 } & Significantly worried & $14.8 \%(\mathrm{n}: 43)$ \\
\cline { 2 - 3 } $\begin{array}{l}\text { What is your level of worry about your } \\
\text { future social life regarding COVID-19 } \\
\text { disease? }\end{array}$ & Severely worried & $14.1 \%(\mathrm{n}: 41)$ \\
\cline { 2 - 3 } & Mildly worried & $31.4 \%(\mathrm{n}: 91)$ \\
\cline { 2 - 3 } & Somewhat worried & $24.1 \%(\mathrm{n}: 70)$ \\
\cline { 2 - 3 } & Not worried at all & $20.3 \%(\mathrm{n}: 59)$ \\
\cline { 2 - 3 } $\begin{array}{l}\text { What is your level of worry about your and } \\
\text { your family's future economic life } \\
\text { regarding COVID-19 disease? }\end{array}$ & Severely worried & $14.1 \%(\mathrm{n}: 41)$ \\
\cline { 2 - 3 } & Mildly worried & $26.9 \%(\mathrm{n}: 29)$ \\
\cline { 2 - 3 } & Not worried at all & $25.5 \%(\mathrm{n}: 74)$ \\
\cline { 2 - 3 } & Somewhat worried & $20.0 \%(\mathrm{n}: 58)$ \\
\cline { 2 - 3 } & Significantly worried & $19.7 \%(\mathrm{n}: 57)$ \\
\hline
\end{tabular}


Table 5. Association of anxiety levels with some of the variables

\begin{tabular}{|c|c|c|c|c|c|}
\hline & $\mathrm{x}^{2}$ & $\mathrm{R}^{2}$ & $b(\mathrm{SE})$ & $P$ & OR \\
\hline Model & 82.432 & 0.358 & & 0.001 & \\
\hline Loneliness Scale for the Elderly & & & $0.257(0.041)$ & 0.001 & 1.293 \\
\hline Having a chronic disease & & & $1.271(0.389)$ & 0.001 & 3.559 \\
\hline $\begin{array}{l}\text { History of a psychiatric disorder prior to } \\
\text { the pandemic }\end{array}$ & & & $1.351(0.503)$ & 0.007 & 3.259 \\
\hline Constant & & & $1.436(5.96)$ & 0.001 & \\
\hline
\end{tabular}

Age, smoking status, Loneliness Scale for the Elderly, Having a chronic disease, History of a psychiatric disorder prior to the pandemic, Information status of the participants added to the analysis and the remaining variables in the model were shown . GAS score 10 was accepted as cut -off point, and logistic regression analysis was applied with the retrospective elimination between groups. The model was significant $\left(\mathrm{x}^{2}: 82.432\right.$, Nagelkerke $\left.\mathrm{R}^{2}: 0.358, \mathrm{p}: 0.001\right)$.

from television.

Our findings show that television is the most common source of information similar to other members of society. During the pandemic periods, the agenda of the media is changing rapidly, and most of the news cover the pandemic. Therefore, governments must establish close relationships with media outlets. Furthermore, studies have found that all sources of information contain false news which does not comply with public health policies (24). News reports announcing that older adults have a higher risk of mortality or are more likely to spread the virus may increase loneliness, fear, and anxiety in elderly individuals (25). However, understanding the rules is particularly important in terms of adapting to changing practices in outbreak management (26). The isolation implemented on individuals aged 65 and over was removed entirely in June, under the restricted conditions such as going out in the walking distance, keeping social distance and wearing a mask. The rules must be clear and reached by many of the individuals as possible so that the society can comply with the changes in practices. The content of messages given by the authorities in the previous SARS epidemic was not explicit, and differences in practices confused the society (27). Accordingly, we concur that the authorities should cooperate and be well-coordinated with television channels to inform the public about the measures taken and the course of the disease.

Our observations representing significant worries about the individuals in the family, future social and economic lives may be consequences of many reasons. A lot has changed in the lives of elderly individuals due to the pandemic. The main reason for increased anxiety about their economic situation was the decrease in social support, especially of the individuals living alone at the beginning of the pandemic. The feeling of anxiety and fear increased even more due to decreased daily care services (16). On the other hand, individuals with chronic illnesses could not get the necessary medical support owing to the bustling healthcare system caused by the pandemic. They did not even want to be checked up for their routine examinations because of the fear of viral contamination (28). Afterwards, the drug and food needs of the elderly were tried to be met with the increase in social support services. Along with the efforts to reduce the economic problems, the psychological support services were established to reduce the mental problems of elderly individuals. The results of our study emphasize that it is essential to meet the economic needs first before spiritual needs.

We observed a positive correlation between anxiety and loneliness scales. Studies have shown that home quarantine is strongly linked to depression, anxiety, and cognitive disorders, and individuals' feelings of self-worth and a sense of purpose are reduced in this condition (29). By our study, it was reported that increased loneliness due to social isolation in the quarantine might increase psychopathologies (30). Social communication is incredibly important, especially for the mental health of elderly individuals. Therefore, being socially distant results in permanent effects on mental and physical health by causing uncertainty, insecurity and negative emotions and affects the quality of life negatively (31). Social networks are developed through Facebook, Twitter, WhatsApp and other online applications by other countries to support the elderly individuals socially, for example, with the National Neighborhood Monitoring Program, established in the UK, people are encouraged to go online and talk via WhatsApp. Also, the Nextdoor Application established in the 
The anxiety and loneliness levels of geriatric population inhome quarantine during COVID-19 pandemic in Turkey

UK aimed to increase the sense of belonging. The application of online treatments such as cognitive behavioural therapy, the feeling of loneliness has been shown to decrease (32).

In our study, anxiety and loneliness levels of individuals aged 65 and over were examined, and more detailed information was obtained about the areas of concern. Meeting the economic, mental, social, and physical health needs of elderly individuals, knowing where to ask for help when in need in public health crises such as pandemics help to reduce psychopathologies that may develop. To minimize the adverse effects of social isolation and loneliness in the quarantine period, charities, support units, and health services should all be organized.

\section{Acknowledgement}

The authors would like to thank to Uzm. Dr Şenay Kilincel for study design.

Correspondence address: M. D. Gurkan Muratdagı, Sakarya University Faculty Of Medicine, Department Of Family Medicine, Sakarya, Turkey, drgm54@gmail.com

\section{REFERENCES}

1. Ge H, Wang X, Yuan X, Xiao G, Wang C, Deng T, Yuan Q, Xiao $X$. The epidemiology and clinical information about COVID-19. Eur J Clin Microbiol Infect Dis. 2020;39:1011-1019. https://doi.org/10.1007/s10096-020-03874-z

2. Demirbilek Y, Pehlivantürk G, Özgüler ZÖ, Alp Meşe E. COVID-19 outbreak control, example of ministry of health of Turkey. Turk J Med Sci. 2020;50:489-494. https://doi.org/10.3906/sag-2004-187

3. Kunz R, Minder M. COVID-19 pandemic: palliative care for elderly and frail patients at home and in residential and nursing homes. Swiss Med Wkly. 2020 Mar 24;150:w20235. https://doi.org/10.4414/smw.2020.20235

4. Verity R, Okell LC, Dorigatti I, Winskill P, Whittaker C, Imai N, Cuomo-Dannenburg G, Thompson H, Walker PGT, Fu H, Dighe A, Griffin JT, Baguelin M, Bhatia S, Boonyasiri A, Cori A, Cucunubá Z, FitzJohn R, Gaythorpe K, Green W, Hamlet A, Hinsley W, Laydon D, Nedjati-Gilani G, Riley S, van Elsland S, Volz E, Wang H, Wang Y, Xi X, Donnelly CA, Ghani AC, Ferguson NM. Estimates of the severity of coronavirus disease 2019: a model-based analysis. Lancet. Infect. Dis. 2020;3099:19. https://doi.org/10.1016/s1473-3099(20)30243-7

5.https://www.phc.ox.ac.uk/covid19/evidenceservice/reviews/glo bal-covid-19-case-fatality-rates. Access date:14.07.2020

6. Galea S, Merchant RM, Lurie N. The Mental Health Consequences of COVID-19 and Physical Distancing: The Need for Prevention and Early Intervention. JAMA Intern Med. 2020;180:817-818

7. Brooke J, Jackson D. Older people and COVID-19: Isolation, risk and ageism. J Clin Nurs. 20201;29:2044-2046. https://doi.org/10.1111/jocn.15274

8. Tanskanen J, Anttila T. A Prospective Study of Social Isolation, Loneliness, and Mortality in Finland. Am J Public Health. 2016;106:2042-2048.

9. Victor C, Scambler, S, Bowling A, Bond J. The prevalence of, and risk factors for, loneliness in later life: a survey of older people in Great Britain. Ageing and Society. 2005;25:357-375. https://doi.org/10.1017/s0144686x04003332

10. Gerst-Emerson K, Jayawardhana J. Loneliness as a public health issue: the impact of loneliness on health care utilization among older adults. Am J Public Health. 2015;105:1013-9. https://doi.org/10.2105/ajph.2014.302427

11. Santini ZI, Jose PE, York Cornwell E, Koyanagi A, Nielsen L, Hinrichsen C, Meilstrup C, Madsen KR, Koushede V. Social disconnectedness, perceived isolation, and symptoms of depression and anxiety among older Americans (NSHAP): a longitudinal mediation analysis. Lancet Public Health. 2020 Jan;5(1):e62e70. https://doi.org/10.1016/S2468-2667(19)30230-0

12. Brennan J, Reilly P, Cuskelly K, Donnelly S. Social work, mental health, older people and COVID-19. Int Psychogeriatr. 2020;12:1-5. https://doi.org/10.1017/S1041610220000873

13. Armitage R, Nellums LB. COVID-19 and the consequences of isolating the elderly. Lancet Public Health. 2020 May;5(5):e256. https://doi.org/10.1016/S2468-2667(20)30061-X

14. Admin, B. B. Campaign to End Loneliness | UK Charity |. Campaign to End Loneliness. https://www.campaigntoendloneliness.org Access date:14.07.2020

15. New Zealand Positive Ageing Strategy (2001). Ministry of Social Development. https://www.msd.govt.nz/about-msd-andour-work/publications-resources/planning-strategy/positive-ageing/ Access date:14.07.2020

16. Wand APF, Zhong BL, Chiu HFK, Draper B, De Leo D. COVID-19: the implications for suicide in older adults. Int Psychogeriatr. 2020;30:1-6.

17. Wang PW, Lu WH, Ko NY, Chen YL, Li DJ, Chang YP, Yen CF. COVID-19-Related Information Sources and the Relationship With Confidence in People Coping with COVID19: Facebook Survey Study in Taiwan. J Med Internet Res. 2020 Jun 5;22(6):e20021. https://doi.org/10.2196/20021

18. Fässberg MM, Cheung G, Canetto SS, Erlangsen A, Lapierre S, Lindner R, Draper B, Gallo JJ, Wong C, Wu J, Duberstein P, Wærn M. A systematic review of physical illness, functional disability, and suicidal behaviour among older adults. Aging Ment Health. 2016;20:166-94.

19. Giallonardo V, Sampogna G, Del Vecchio V, Luciano M, Albert U, Carmassi C, Carrà G, Cirulli F, Dell'Osso B, Nanni MG, Pompili M, Sani G, Tortorella A, Volpe U, Fiorillo A. The 
Impact of Quarantine and Physical Distancing Following COVID-19 on Mental Health: Study Protocol of a Multicentric Italian Population Trial. Front Psychiatry. 2020 Jun 5;11:533. https://doi.org/10.3389/fpsyt.2020.00533

20. Pachana NA, Byrne GJ, Siddle H, Koloski N, Harley E, Arnold E. Development and validation of the Geriatric Anxiety Inventory. Int Psychogeriatr. 2007;19:103-14.

21. Karahan FS, Hamarta E, Karahan AY. The Turkish adaptation and psychometric properties of the Geriatric Anxiety Scale. Ment Illn. 2018;10:7580. https://doi.org/10.4081/mi.2018.7580

22. Jong-Gierveld J, Tilburg TG. Manual of the Loneliness Scale 1999. Department of Social Research Methodology, Vrije Universiteit. 1999.

23. Akgül H, Yeşilyaprak B. Yaşlılar için yalnızlık ölçeği'nin Türk kültürüne uyarlaması: Geçerlilik ve Güvenirlik Çalışması. Yaşlı Sorunları Araştırma Dergisi. 2015(1):34-45.

24. Fineberg HV. Preparing for avian influenza: lessons from the "swine flu affair". J Infect Dis. 2008 Feb 15;197 (Suppl 1):S14-8. https://doi.org/10.1086/524989

25. Webb L. COVID-19 lockdown: A perfect storm for older people's mental health. J Psychiatr Ment Health Nurs. 2020 Apr 30:10.1111/jpm.12644. https://doi:10.1111/jpm.12644

26. Kavanagh AM, Bentley RJ, Mason KE, McVernon J, Petrony S, Fielding J, LaMontagne AD, Studdert DM. Sources, perceived usefulness and understanding of information disseminated to families who entered home quarantine during the H1N1 pandemic in Victoria, Australia: a cross-sectional study. BMC Infect Dis. 2011;4:11:2.

27. DiGiovanni C, Conley J, Chiu D, Zaborski J. Factors influencing compliance with quarantine in Toronto during the 2003 SARS outbreak. Biosecur Bioterror. 2004;2:265-72. https://doi.org/10.1089/bsp.2004.2.265

28. Yang Y, Li W, Zhang Q, Zhang L, Cheung T, Xiang YT. Mental health services for older adults in China during the COVID-19 outbreak. Lancet Psychiatry. 2020;7:e19. https://doi.org/10.1016/s2215-0366(20)30079-1

29. Novotney, A. The risks of social isolation. Monitor on Psychology, 50(5). http://www.apa.org/monitor/2019/05/ce-corner-isolation Access date:14.07.2020

30. Read S, Comas-Herrera A, Grundy E. Social Isolation and Memory Decline in Later-life. J Gerontol B Psychol Sci Soc Sci. 2020;75:367-376. https://doi.org/10.1093/geronb/gbz152

31. Schwartz E, Shrira A. Social Connectedness Moderates the Relationship Between Warfare Exposure, PTSD Symptoms, and Health Among Older Adults. Psychiatry. 2019;82:158-172. https://doi.org/10.1080/00332747.2018.1534521

32. Käll A, Jägholm S, Hesser H, Andersson F, Mathaldi A, Norkvist BT, Shafran R, Andersson G. Internet-Based Cognitive Behavior Therapy for Loneliness: A Pilot Randomized Controlled Trial. Behav Ther. 2020;51:54-68. https://doi.org/10.1016/j.beth.2019.05.001 